\title{
Fluid inclusions from the deep Dead Sea sediment provide new insights on Holocene extreme microbial life
}

Thomas C. ${ }^{1 *}$ and Ariztegui D. ${ }^{1}$

${ }^{1}$ Department of Earth Sciences, University of Geneva, 1205 Geneva, Switzerland

* Corresponding author : Camille.thomas@unige.ch

\begin{abstract}
The Dead Sea Deep Drilling Project allowed to retrieve a continuous sedimentary record spanning the two last glacial cycles. This unique archive, in such an extreme environment, has allowed for the development of new proxies and the refinement of already available paleoenvironmental studies. In particular, the interaction of the lake and sediment biosphere with elements and minerals that constitute paleoclimatic proxies has been emphasized. Although life is pushed to its extremes in the Dead Sea environment, several studies have highlighted the impact of microbial activity on this harsh milieu. The paradox is that the identity and means of adaptation of these organisms are largely ignored. We also know relatively little on the way this extreme ecosystem has evolved with time, and how it will react to growing pressure. Constraining this gap should allow to gain precision on the use of paleoenvironmental studies, and also assess the impact of human activity and climate change on a rare ecosystem. In this study, we use halite, the main evaporitic phase during arid periods in the Dead Sea basin and extract ancient DNA from their fluid inclusions, in order to characterize the ancient life of the Holocene Dead Sea. With the aid of an accurately designed protocol, we obtained fossil bacterial and archaeal 16S rRNA gene sequences that illustrate that the main microbial actors of the present Dead Sea have been present in the lake for a relatively long period, emphasizing the stability of this extreme environment. Additionally, we show that current phylotypes of the deep biosphere are present within the obtained fluid inclusions sequences, which would support seeding of the deep biosphere from the water column. Finally, we shed light on putative new actors of the sulfur cycle involving both archaea and bacteria, which could play an unexpected role in the reduction of sulfur species. Together, these data provide new research avenues for both geologists and biologists working in this extreme environment, and help understanding the evolution of the Dead Sea ecosystem with time.
\end{abstract}

Keywords:

Holocene; Paleolimnology; Middle East ; Continental biomarkers ; Paleomicrobiology 


\section{Introduction}

The goal of every paleo-environmental study is to reconstruct the conditions of life at a given time and in a given space, using a set of direct or indirect indicators, called proxy. One of the targets is often to qualify and quantify the extent of the diversity of a given paleo-ecosystem, and its impact on the environment, in order to analyse its evolution in time, and ideally predicts its future trajectory. Sites of particular interests are those that are today in danger, e.g. in the verge of disappearing, or to be profoundly modified. While these ecosystems become increasingly numerous on our planet, the need for paleo-ecological or paleo-environmental studies, that can be used for comparing with the current states of endangered ecosystems is continuously growing.

Since more than 50 years now, the Dead Sea water budget has been negative, resulting in a massive drop of the shoreline at a rate exceeding one meter per year in the last decade. Halite is almost constantly precipitating and the total dissolved salt concentration has reached the highest level on Earth with up to 348 g. L L $^{-1}$ (Oren and Gunde-Cimerman, 2012). The Dead Sea is therefore an extreme ecosystem characterized by a high concentration of divalent cations ( $\sim 2$ $\mathrm{M} \mathrm{Mg}^{2+}$ and $\sim 0.5 \mathrm{M} \mathrm{Ca}^{2+}$ ), which makes it a specifically harsh environment for microorganisms that remain the only inhabitants of its water (Oren, 2001). Except for some oases of life located at the outflow of groundwater springs, the number of organism is extremely low in the present Dead Sea water $\left(<10^{4}\right.$; Ionescu et al., 2012). Given the extreme (osmotic) pressure put on organisms, the Dead Sea flora is composed today uniquely of halophilic prokaryotes. The only eukaryote and primary producer in the Dead Sea water is the alga Dunaliella, which blooms periodically when the surface layer has been diluted enough by heavy rainfalls over the Jordan catchment area and the surroundings of the Dead Sea (Oren et al., 1995). These events have not occurred since 1992 and the Dead Sea ecosystem has now become so extreme that it is mainly inhabited by halophilic archaea of the Halobacteria family, most of them remaining unclassified, or belonging to the Halorhabdus genus (Bodaker et al., 2010; Jacob et al., 2017). The sediment of the Dead Sea is similarly dominated by these phylotypes, and recent studies have argued that the water column communities seed the sedimentary ones, or at least strongly affect the conditions of development of its subsurface biosphere (Ariztegui et al., 2015; Thomas et al., 2015).

However, paleoenvironmental studies using sulfur or carbon isotopes, lipid biomarkers or other biosignatures contained in its sediments have shown that the ancestral Dead Sea hosted more diverse metabolisms. Gypsum minerals for example exhibit specific sulfur isotopic signatures 
that are characteristic of sulfate reduction activity (e.g. Torfstein et al., 2005). It is also the case for magnetic minerals such as greigite or titanomagnetite (Ebert et al., 2018; Thomas et al., 2016). The microorganisms responsible for this sulfate reduction however remain unknown. Recently, biomarker evidences also highlighted the recycling of halophilic archaeal membrane by unknown bacterial communities in the deep halite levels of the Dead Sea (Thomas et al., 2018) which constitute a new step in the Dead Sea sedimentary carbon cycle and likely contributes in modifying the pool of sedimentary organic matter of this hypersaline environment. But these bacteria have not been identified and very little information is overall available on the Dead Sea bacterial communities.

As a result, a more precise understanding of the composition of microbial communities of the ancient Dead Sea is critical to fill these gaps and shall help characterizing the paleobiogeochemical conditions leading to the preservation of proxies for paleoclimatic studies. It is also pivotal in understanding how this ecosystem has evolved in the past and how it will react to the increasing pressure on water in the Levantine region (Tahal Group et al., 2011).

Gaining access to these microbial paleocommunities is, however, a complicate matter. The search of lipid biomarkers or mineral biosignatures in bulk sediments lacks in precision and specificity. Additionally, allochtonous organic matter may hide signatures from the Dead Sea paleo-biosphere. We here use the organic fraction preserved in fluid inclusions of halite crystals from salt levels in the deepest core retrieved during the Dead Sea Deep Drilling Project. Fluid inclusions are micrometric cavities that form in the lattice of minerals due to differential precipitation rates. They are particularly numerous in halite, where they trap the fluid from which the crystal precipitated. Providing they remain pristine between their formation and their sampling, they constitute excellent time capsules to capture the chemistry and biology of the water at the time and locus of precipitation. Previous investigations have shown that halite fluid inclusions could preserve DNA of microbial communities as old as $150 \mathrm{ka}$ (Sankaranarayanan et al., 2011). A number of studies also discuss the potential for these fluid inclusions to preserve viable microbes beyond several hundred millions of years (Satterfield et al., 2005; Vreeland et al., 2007, 2000). Although such results are controversial (e.g. Graur and Pupko, 2000) and beyond the scope of this paper, they show that fluid inclusions harbour a large potential for the study of paleo-conditions of life in the Dead Sea during most arid circumstances. Therefore, their study could further illuminate the Dead Sea paleo-biosphere and better constrain its evolution towards current extremes. 


\section{Material and methods}

Core-catcher sediments from DSDDP core 5017-1A (see Neugebauer et al., 2014 for details) have been sampled onshore directly after drilling in December 2010. Specific care was taken to avoid any external or trans-contamination. Right after each drilling shift, cores and corecatchers were brought to the shore and stored in a cooling room $\left(4^{\circ} \mathrm{C}\right)$. Core-catchers were then opened in a specially arranged geomicrobiology lab and sampled for microbiological studies using sterilized clamps and syringes. All samples were stored at $-8{ }^{\circ} \mathrm{C}$ before further processing. Samples containing halite were selected along the first $200 \mathrm{~m}$ of the core. Aliquots were subsampled for microscopic examination under visible and UV light. Pictures of the samples were then taken during core-opening parties at the GFZ of Potsdam.

The recovery of ancient DNA is always an issue in sedimentary samples. It is also the case when working with halite fluid inclusions. As a result, extreme care has been taken to avoid contamination from modern microbes and extraction of DNA and subsequent amplification and cloning of $16 \mathrm{~S}$ rRNA gene was realized following a protocol tailored specifically for halite fluid inclusions and such little quantity of ancient DNA (Sankaranarayanan et al., 2011). Samples were spiked with known DNA before sterilization of the external walls of the halite crystals with the acid bleach protocol from Sankaranarayanan et al. (2011). Crystals of halite were first soaked in $10 \mathrm{~N} \mathrm{HCl}$ prepared at minimal halite solubility for 15 minutes. They were then transported to a neutralization solution of $\mathrm{Na}_{2} \mathrm{CO}_{3} 10 \%$ prepared at halite saturation and to $6 \% \mathrm{NaOCl}$ (at halite saturation), for 15 minutes for both. Rinsing in an autoclaved halite saturated brine was performed between each step, in order to avoid reagent carryover, and a final set of 4 washes of 15 minutes each, was done to secure the complete cleansing of the halite crystal walls. After dissolution to $1 \mathrm{M}$, samples are further desalted using Amicon Centrifugal filters (Ultra-0.5 $50 \mathrm{kDa}$, YM50, Millipore). The filters allow for the trapping of DNA fragments longer than $50 \mathrm{bp}$ only. These fragments were further purified using a minElute PCR Purification Kit (Qiagen). Obtained DNA was quantified using a Nanodrop ${ }^{\circledR}$ ND-1000 Spectrophotometer (Witec AG). To recover sufficient amount of DNA for cloning, an initial PCR done using the universal primers 4F (5'-TCYGGTTGATCCTGCCRG-3') and Univ1492R (5'-CGGTTACCTTGTTACGACTT-3') (Dong et al., 2006) was followed by a nested PCR with $1 \mu \mathrm{L}$ of PCR using the 3F (5'-TTCCGGTTGATCCTGCCGGA-3') \& 9R (5'CCCGCCATTCCTTTAAGTTTC-3') primers for Archaea (Jurgens et al., 1997). For Bacteria, we used 27F (5'-AGAGTTTGATCCTGGCTCAG-3') and 1492R (5'GGTTACCTTGTTACGACTT-3') followed by $341 \mathrm{~F}$ (5'- 
CTCCTACGGGAGGCAGCAGTGGGGAATATTGC-3') and 907R (5'CCGTCAATTCCTTTRAGTTT-3') (Lane, 1991; Weisburg et al., 1991; Muyzer et al., 1993). DNA fragments were amplified using the following protocole. For Archaea, initial denaturation for $5 \mathrm{~min}$ at $95^{\circ} \mathrm{C}, 30$ cycles of denaturation of $1 \mathrm{~min}$ at $95^{\circ} \mathrm{C}$, annealation of $1 \mathrm{~min}$ at $53^{\circ} \mathrm{C}$ and elongation for $2 \mathrm{~min}$ at $72^{\circ} \mathrm{C}$. Final elongation was run for $5 \mathrm{~min}$ at $72^{\circ} \mathrm{C}$. For Bacteria, initial denaturation was run for $2 \mathrm{~min}$ at $94^{\circ} \mathrm{C}$, and 30 cycles of denaturation at $94^{\circ} \mathrm{C}$ for $30 \mathrm{sec}$, annealation for $30 \mathrm{sec}$ at $52^{\circ} \mathrm{C}$ and elongation for $1 \mathrm{~min} 30 \mathrm{sec}$ at $72^{\circ} \mathrm{C}$. Final elongation was performed at $72^{\circ} \mathrm{C}$ for 5 min. After purification with High Pure ${ }^{\circledR}$ PCR product Purification Kit (Roche Diagnostic SA), the products were cloned using the TOPO TA Cloning Kit (InvitrogenTM by Life TechnologiesTM) following the manufacturer's instructions. Positive clones were verified by PCR and subsequently prepared for sequencing using the BigDye ${ }^{\circledR}$ Terminator v3.1 Cycle Sequencing Kit (Applied BioSystems) with primers D4 and R5. Sequencing was performed on an ABIPRISM ${ }^{\circledR}$ 3130xl Genetic Analyzer (Applied BioSystems, Hitachi). All samples yielded positive results (i.e. non-contaminant sequences) except for sample A-82 (206,53 mblf) that never yielded positive clones. Sequences were cleaned, assembled, trimmed to around 550 nucleotides and aligned using CodonCode Aligner@ v.3.7.1 (CodonCode Corporation) and MEGA (Kumar et al., 2016). Sequences were checked for chimeras using Bellerophon (Huber et al., 2004) and reference sequences were obtained using the NCBI genbank ${ }^{\circledR}$. A phylogenetic tree was built through the Weighted Neighbor Joining method (Bruno et al., 2000) under MEGA using 999 bootstrap, and was rooted with Methanopyrus Kandleri. Genetic distance with the closest neighbour were also calculated using MEGA. All sequences are available on the Open Science Framework project page https://osf.io/xbj3w/.

\section{Results}

\subsection{Sedimentary analysis}

The investigated halite layers could be divided into three different facies (Fig. 1). Sample A-1 is composed of small cumulate crystals. Sample A-2 is a mix of small cumulate crystals and large transparent crystals. Sample A-21 is formed of large transparent halite crystals. Samples A-26, A-42 and A-82 are formed of alternations of small raft crystals and large transparent ones. According to Kiro et al. (2016), small cumulate crystals (rafts) precipitate from the surface of the Dead Sea water column while large transparent ones form in the bottom. As a result, 
small cumulate crystals may contain only microorganisms from the photic zone, while large transparent ones may harbor communities from the deep layers, the sediment interface, as well as those that have sedimented to the bottom of the lake (after cell death for example).

Microscopic investigation permitted to identify pristine fluid inclusions in all samples (Fig. 2A and $2 \mathrm{~B}$ ). Some of them harbored dark filaments or spots that may correspond to microbial cells. However, the small size of the putative organisms and the limited visibility through halite crystals prevented univocal interpretations (Fig. 2C). Under UV light, autofluoresence could confirm that these elements were of organic origin (Fig. 2D), but did not permit to assert whether they were allochthonous organic matter fragments, or actual microbial cells. In only one sample (A-2 at $1.3 \mathrm{~m}$ below lake floor, mblf) a green algal cell from the Dunaliella genus has been identified given its higher size, shape and red color (Fig. 2B). This halite interval has been interpreted as precipitated during the anomalously wet winter of 1991-1992 (Kiro et al., 2016) that triggered a bloom of Dunaliella (Oren et al., 1995). Hence, it is very likely that this Dunaliella cell is a "survivor" of this very bloom.

\subsection{Microbiological analysis}

In total, 15 different Operational Taxonomic Unit (OTU) - a unit used to classify groups of closely related individuals - (9 from Archaea and 6 from Bacteria) were retrieved from 5 different halite samples (Table 1). No sequence could be recovered from samples deeper than 87.6 mblf, potentially setting up a limit to the preservation of fossil DNA in the Dead Sea halite fluid inclusions to the beginning of the Holocene (estimated age of the halite level at $87.6 \mathrm{mblf}$, (Neugebauer et al., 2014).

At 0.24 mblf, one OTU was assigned to the halophilic archaeal family Halobacteriaceae (genus Halorussus, Minegishi et al., 2011) and one OTU was related to a Gammaproteobacteria of the genus Marinobacter (Chang et al., 2012). At 1.3 mblf, only one archaeal OTU could be retrieved and was associated to the sulfur reducing archaeal genus Halodesulfurarchaeum (Cytryn et al., 2000). At 32.9 mblf, one bacterial OTU was obtained and was related to the Clostridia Halanaerobium genus (Podell et al., 2013). The halite sample at 48.12 mblf yielded 9 OTUs, among which 2 were assigned to Bacteria. The first one was closely associated to uncultured Acetothermia (98 \% identity, Emmerich et al., 2012) (Fig. 4) and one assigned to the Alphaproteobacteria Rhodovibrio genus (Atanasova et al., 2012). Archaeal OTUs were all related to Euryarchaeota. Four OTUs were related to the Halobacteria class and 3 of them were associated to the Haloferacaceae family (genus Salinarchaeum ; Grant et al., 1999; Mesbah et 
al., 2007). The other Halobacteria related OTUs was assigned to the uncultured MSP41-clade (Rubin et al., 2017). The other Euryarchaeota were associated to the Nanoarchaeaeota class (Narasingarao et al., 2012). Finally, two bacterial OTUs were obtained from a halite sample at 87.6 mblf, and were assigned to Acetothermia (Emmerich et al., 2012) and to the Desulfovermiculus genus of Gammaproteobacteria (Dillon et al., 2013).

Overall, we obtained a relatively small number of non-contaminant OTUs from halite levels. This is in line with the little amount of material studied, and speculated extremely low number of microbial cells in the paleo-Dead Sea. The oldest DNA sequence dates back to the beginning of the Holocene. They encompass both archaeal and bacterial halophilic representatives that bear new information on the evolution of the extreme microbial ecosystem of the Dead Sea during the current interglacial period.

\section{Discussion}

Halite is known to deposit in the Dead Sea during periods of low freshwater inputs and intense evaporation. These conditions have dominated along the Holocene, and together with the human activity have contributed to lowering the lake level and increasing its salinity to its minimum current level. During the Holocene, $\mathrm{Mg}^{2+}$ concentrations never exceeded the current values but total dissolved salt (TDS) may have reached similar levels (Levy et al., 2018, 2017). We therefore have likely reached today an extreme in terms of microbial life conditions (Oren, 2010).

The Dead Sea life is currently limited to halophilic prokaryotes, which mainly belong to Archaea of the Halobacteria class. They are the principal inhabitants of the Dead Sea brine (Bodaker et al., 2010; Jacob et al., 2017) and of its shallow sediment (Ionescu et al., 2012; Thomas et al., 2015). Jacob et al. (2017) also identified bacterial sequences using universal prokaryotic primers for the $16 \mathrm{~S}$ rRNA gene. However, these sequences do not belong to halophilic organisms and some of them are common lab contaminants (Sheik et al., 2018), so must be taken very cautiously, the Dead Sea water being very poor in microbial cells and therefore prone to contamination. Bacterial presence was outlined in several studies, mainly concentrated in the vicinity of freshwater springs (Häusler et al., 2014; Ionescu et al., 2012) where reduced salinities allow their development. Similarly, eukaryotic cells have been outlined after heavy rain episodes, during which they may form red blooms of Dunaliella algae 
providing sufficient dilution of the epilimnion (Oren, 1993, 1983). Finally, several fungal species have also been isolated although their contribution to the Dead Sea ecosystem is poorly known (Oren and Gunde-Cimerman, 2012).

\subsection{Ancient archaeal communities}

Our results show that the presence of halophilic archaea has been common during most haliteprecipitating periods of the Holocene. The dominance of Halobacteriaceae sequences, and more precisely from the genus Salinarchaeum (named Halorhabdus in the NCBI database) is a common feature of the present Dead Sea community, both in the water column (Bodaker et al., 2010; Jacob et al., 2017) and in the halite sediment (Thomas et al., 2015). It seems that this genus has inhabited the Dead Sea water column for a long time, as similarly affiliated sequences were retrieved in the $48.12 \mathrm{mblf}$ halite, which age is estimated by ${ }^{14} \mathrm{C}$ at $6640 \pm 45 \mathrm{BP}$ (Kitagawa et al., 2016). Salinarchaeum/Halorhabdus members have been acknowledged to be highly versatile and may grow in oxic and anoxic environments, preventing any inference on their environmental niche (Werner et al., 2014). Halobacteria members from the MSP41-clade, recovered in fluid inclusions at $48.12 \mathrm{mblf}$, had also been identified through their 16S rRNA gene sequence in the most recent halite deposits of the deep Dead Sea (Thomas et al., 2015), and seem to be also stable inhabitants of the lake waters. Uncultured Archaea like Nanohaloarchaea have been identified through the sequences of the DS fluid inclusions at 48.12 mblf. Metagenomics data from this class show that they are likely to live in aerobic conditions (Narasingarao et al., 2012) suggesting that they inhabited the Dead Sea water column $6.6 \mathrm{ky}$ ago. No trace of their presence has been recorded in the modern lake but two sequences associated to this lineage were recovered from a microbial mat collected in the vicinity of the Dead Sea, which harbored less extreme conditions than the Dead Sea sediment itself (Thomas et al., 2015). Chlorine and magnesium porewater concentrations suggest that the lake was higher and less hypersaline at that period, potentially allowing these organisms to develop, while a current salinity threshold may have been reached and may prevent their presence. Cultivation of members of the novel class Nanohaloarchaea, the second archaeal lineage to host halophilic organisms (Aouad et al., 2018), should help refine the limits for their development (Oren, 2015).

Interestingly, an OTU associated to the Halodesulfurarchaeum genus has been identified for the first time in the Dead Sea (in halite at $1.3 \mathrm{mblf}$ ). They represent the first trace of identified sulfur reducing archaea in this environment. Their reliance on elemental sulfur, thiosulfate or 
DMSO as electron acceptor and on formate or hydrogen as electron donor make them relatively versatile organisms able to compete with heterotrophic or lithototrophic organisms (Sorokin et al., 2017). While these results are only preliminary, they suggest a complex sulfur cycle in the Dead Sea, with stepwise degradation of sulfur species likely involving consortia of archaea and bacteria. This could possibly be reflected in the sulfur isotopes of reduced compounds (iron sulfides, concretions) and of their residual products (Bishop et al., 2013; Torfstein et al., 2005).

\subsection{Ancient bacterial communities}

The bacterial actor of this sulfur reduction might be linked to Desulfovermiculus of the Desulfohalobiaceae family (Gammaproteobacteria; Table 1), whose 16S rRNA gene sequence was recovered from the halite layer at 87,6 mblf. This is less than one meter above gypsum layers marking the transition between the late Pleistocene stratified Lake Lisan and the early Holocene Dead Sea (Neugebauer et al., 2014; Torfstein et al., 2008), which could thus explain the persistence of this anaerobe in halite fluid inclusions.

Two other halophilic bacterial anaerobes were identified through their fluid inclusion $16 \mathrm{~S}$ rRNA gene sequences: Halanaerobium and Acethothermia. The age of the halite from which Halanaerobium sequences have been recovered is estimated between $4130 \pm 40$ and $4815 \pm 35$ BP (Kitagawa et al., 2016), a period during which the lake level may have had comparable levels and salinity than today (Levy et al., 2017). Similar organisms were previously identified in a microbial mat in the vicinity of the Dead Sea (Thomas et al., 2015), where salinity was alike the modern Dead Sea. Acethormia-related sequences were retrieved from halite layers at $48.12 \mathrm{~m}$ and $87.6 \mathrm{~m}$ blf. Similar sequences were also retrieved from a microbial mat in the vicinity of the lake and from a layer of authigenic aragonite of the Dead Sea (2.74 mblf; Thomas et al., 2015). They were formerly assigned to the Candidate divison KB1 described from the Kebrit Deep brine in the Red Sea (Eder et al., 1999), but have now been reclassified in the Silva SSU r132 database (Quast et al., 2013) as members of the Acetothermia phylum. However, our sequences cluster within the hypersaline KB1 Division, and out of the thermophilic cluster of Acetothermia. Sequences defining the hypersaline KB1 divisions outlined by Nigro et al. (2016), encompass the closest matches of our sequences and were recovered from deep-sea anoxic brines where high $\mathrm{Mg}^{2+}$ concentrations -a characteristic feature of the Dead Sea waterwere measured (e.g. van der Wielen et al., 2005; Yakimov et al., 2013). We suggest thanks to these new fluid inclusion sequences that these organisms likely persisted in the deep part of the lake, possibly at the water-sediment interface, where they could benefit from sinking organic 
carbon. Several studies show that KB1 organisms feed on glycine betaine, an osmotic solute commonly found in halotolerant to halophilic bacteria using the salt-out/low salt-in strategy (Nigro et al., 2016; Yakimov et al., 2013). These organisms hardly survive in the Dead Sea environment, where osmotic equilibration by the salt-in strategy (adopted by KB1 Candidate Division, Halobacteria and Halanaerobiaceae members) is generally favored (Nigro et al., 2016; Oren, 2008). It is hence possible that KB1 feed on the necromass of halophilic organisms unable to survive in the increasingly harsh conditions of the Dead Sea (Ariztegui et al., 2015; Thomas et al., 2015). The fact that they have not been recovered in the modern lake (Thomas et al., 2015; Jacob et al., 2017) can be explained by increasingly harsh conditions preventing their development or that of halotolerant organisms, which constitute the base of their foodweb. Except for the Marinobacter sequence at $0.24 \mathrm{~m}$, all obtained closest matches were retrieved from hypersaline environments (terrestrial or marine). Sequences related to halotolerant species are not expected to develop in the halite-precipitating Dead Sea water column, salinity conditions presumably being too harsh for them. They have been more likely transported to the lake before being trapped in the fluid inclusion. Finally, the recovery of a halophilic phototrophic sequence of Rhodovibrio, rare in the modern Dead Sea, underlines the potential of fluid inclusion extractions for trapping surficial water column communities to the sediment.

\subsection{Evolution of the Dead Sea ecosytem - An outlook}

The fluid inclusions data provide new information on the diversity and complexity of the Dead Sea microbial ecosystems, in the sediment and the water column. They suggest previously unconsidered actors and point towards new direction regarding the study of paleobiogeochemical cycles of this environment.

The modern Dead Sea ecosystem is one of the harshest on Earth in terms of salinity and divalent cation concentrations. During the Holocene, the lake level has fluctuated and rarely reached as extreme values as today. We show here that although hypersaline conditions have prevailed during the Holocene, short term dilution or lowering of the salinity have allowed the develoment of bacterial members, and poorly known archaeal organisms. It is the case of KB1/Acetothermia, MSP41 or Halanaerobium. They may have persisted in more favorable environments such as those provided by freshwater springs near the Dead Sea shores (Häusler et al., 2014; Ionescu et al., 2012), which today harbour similar phylotypes (Thomas et al., 2015). Other organisms (Halodesulfurarchaeum, Nanohaloarchaea and Desulfohalobius) are identified in the Dead Sea realm for the first time. It is possible that increasingly harsh 
conditions may have led to their disappearance. It is also possible that the low coverage of certain 16S rRNA gene sequencing (Thomas et al., 2015), poor coverage of halophilic sequences database (Thomas et al., 2014) or specificity of the used primers (Bodaker et al., 2010; Jacob et al., 2017) can contribute to their non-recovery in previous studies.

Important similarities are shared between the deep halite-hosted subsurface biosphere of the Dead Sea (be it of Holocene or older age) and ancient DNA obtained from halite fluid inclusions. Given the extreme attention devoted in avoiding contamination from modern communities, we suggest that these similarities advocate for a seeding of the subsurface biosphere by the lake water column ecosystem. Although data remain scarce to unequivocally prove this pattern, the extreme conditions inherent to this ecosystem is likely to select for organisms within the water column, first for their ability to withstand osmotic pressure. In addition to being extreme halophiles, the dominant organisms (namely Halorhabdus/ Salinarchaeum) of the sediment and the water column have the potential for developing in both oxic and anoxic environments. This versatility may very well be a favored trait in the Dead Sea subsurface ecosystem. Local environmental conditions, are therefore likely to be reflected in both the paleo and modern sedimentary communities.

While a unique ecosytem has managed to adapt to the extreme conditions of the Dead Sea, it seems that the pressure on this environment will keep on growing, and little is known on the way microbes will react. Their adaptative ability is immense and already overcomes numerous limitations imposed by the medium. Our current work provide avenues for the study of these limitations and associated adaptations, and shows that although extreme, such organisms are indeed affected by environmental changes.

Data availability

The data are available on the Open Science Framework project page https://osf.io/xbj3w/.

\section{Acknowledgements}

This research was funded by the Swiss National Science Foundation(projects 200021-132529 and 200020-149221/1). We thank Aurèle Vuillemin, Nicolas Waldmann and Emanuela Reo for their contribution to the field and lab work, as well as Aymeric Le Cotonnec and Romain Vaucher for their help during sampling in the laboratory. 


\section{References}

Aouad, M., Taib, N., Oudart, A., Lecocq, M., Gouy, M., Brochier-Armanet, C., 2018. Extreme halophilic archaea derive from two distinct methanogen Class II lineages. Mol. Phylogenet. Evol. doi:10.1016/j.ympev.2018.04.011

Ariztegui, D., Thomas, C., Vuillemin, A., 2015. Present and future of subsurface biosphere studies in lacustrine sediments through scientific drilling. Int. J. Earth Sci. 104, 1655 1665.

Atanasova, N.S., Roine, E., Oren, A., Bamford, D.H., Oksanen, H.M., 2012. Global network of specific virus-host interactions in hypersaline environments. Environ. Microbiol. 14, 426-440. doi:10.1111/j.1462-2920.2011.02603.x

Bishop, T., Turchyn, A. V, Sivan, O., 2013. Fire and brimstone: the microbially mediated formation of elemental sulfur nodules from an isotope and major element study in the paleo-Dead Sea. PLoS One 8, e75883. doi:10.1371/journal.pone.0075883

Bodaker, I., Sharon, I., Suzuki, M.T., Feingersch, R., Shmoish, M., Andreishcheva, E., Sogin, M.L., Rosenberg, M., Maguire, M.E., Belkin, S., Oren, A., Béjà, O., 2010. Comparative community genomics in the Dead Sea: an increasingly extreme environment. ISME J. 4, 399-407.

Chang, Y.H., Cheng, T.W., Lai, W.J., Tsai, W.Y., Sun, C.H., Lin, L.H., Wang, P.L., 2012. Microbial methane cycling in a terrestrial mud volcano in eastern Taiwan. Environ. Microbiol. 14, 895-908. doi:10.1111/j.1462-2920.2011.02658.x

Cytryn, E., Minz, D., Cohen, Y., 2000. Distribution and Diversity of Archaea Corresponding to the Limnological. Appl. Environ. Microbiol. 66, 3269.

Dillon, J.G., Carlin, M., Gutierrez, A., Nguyen, V., McLain, N., 2013. Patterns of microbial diversity along a salinity gradient in the Guerrero Negro solar saltern, Baja CA Sur, Mexico. Front. Microbiol. 4, 1-13. doi:10.3389/fmicb.2013.00399

Ebert, Y., Shaar, R., Emmanuel, S., Nowaczyk, N., Stein, M., 2018. Overwriting of sedimentary magnetism by bacterially mediated mineral alteration. Geology 46, 2-5. doi:https://doi.org/10.1130/G39706.1

Eder, W., Ludwig, W., Huber, R., 1999. Novel 16S rRNA gene sequences retrieved from highly saline brine sediments of kebrit deep, red Sea. Arch. Microbiol. 172, 213-218.

Emmerich, M., Bhansali, A., Lösekann-Behrens, T., Schröder, C., Kappler, A., Behrens, S., 2012. Abundance, distribution, and activity of $\mathrm{Fe}(\mathrm{II})$-oxidizing and $\mathrm{Fe}$ (III)-reducing microorganisms in hypersaline sediments of Lake Kasin, southern Russia. Appl. Environ. Microbiol. 78, 4386-4399. doi:10.1128/AEM.07637-11

Grant, S., Grant, W.D., Jones, B.E., Kato, C., Li, L., 1999. Novel archaeal phylotypes from an East African alkaline saltern. Extremophiles 3, 139-45.

Graur, D., Pupko, T., 2000. The Permian Bacterium that Isn’t. Mol. Biol. Evol. 18, 1143 1146.

Häusler, S., Noriega-Ortega, B.E., Polerecky, L., Meyer, V., de Beer, D., Ionescu, D., 2014. Microenvironments of reduced salinity harbour biofilms in Dead Sea underwater springs. Environ. Microbiol. Rep. 6, 152-8. doi:10.1111/1758-2229.12140

Ionescu, D., Siebert, C., Polerecky, L., Munwes, Y.Y., Lott, C., Häusler, S., Bižić-Ionescu, M., Quast, C., Peplies, J., Glöckner, F.O., Ramette, A., Rödiger, T., Dittmar, T., Oren, A., Geyer, S., Stärk, H.-J., Sauter, M., Licha, T., Laronne, J.B., de Beer, D., 2012. 
Microbial and chemical characterization of underwater fresh water springs in the Dead Sea. PLoS One 7, e38319. doi:10.1371/journal.pone.0038319

Jacob, J.H., Hussein, E.I., Shakhatreh, M.A.K., Cornelison, C.T., 2017. Microbial community analysis of the hypersaline water of the Dead Sea using high-throughput amplicon sequencing. Microbiologyopen 6, 1-6. doi:10.1002/mbo3.500

Kiro, Y., Goldstein, S.L., Lazar, B., Stein, M., 2016. Environmental implications of salt facies in the Dead Sea. Geol. Soc. Am. Bull. 128, 824-841. doi:10.1130/B31357.1

Kitagawa, H., Stein, M., Goldstein, S.L., Nakamura, T., Lazar, B., DSDDP Scientific Party, 2016. Radiocarbon chronology of the DSDDP core at the deepest floor of the Dead Sea. Radiocarbon 59, 1-12. doi:10.1017/RDC.2016.120

Kumar, S., Stecher, G., Tamura, K., 2016. MEGA7 : Molecular Evolutionary Genetics Analysis Version 7 . 0 for Bigger Datasets Brief communication. Mol. Biol. Evol. 33, 1870-1874. doi:10.1093/molbev/msw054

Levy, E.J., Stein, M., Lazar, B., Gavrieli, I., Yechieli, Y., Sivan, O., 2017. Pore fluids in Dead Sea sediment core reveal linear response of lake chemistry to global climate changes. Geology 3-6. doi:10.1130/G38685.1

Levy, E.J., Yechieli, Y., Gavrieli, I., Lazar, B., Kiro, Y., Stein, M., Sivan, O., 2018. Salt precipitation and dissolution in the late Quaternary Dead Sea: Evidence as deduced from the chemical and $\delta 37 \mathrm{Cl}$ composition of pore fluids and halites. Earth Planet. Sci. Lett. accepted, 127-137. doi:10.1016/j.epsl.2018.02.003

Mesbah, N.M., Abou-El-Ela, S.H., Wiegel, J., 2007. Novel and unexpected prokaryotic diversity in water and sediments of the alkaline, hypersaline lakes of the Wadi An Natrun, Egypt. Microb. Ecol. 54, 598-617. doi:10.1007/s00248-006-9193-y

Minegishi, H., Kamekura, M., Kitajima-Ihara, T., Nakasone, K., Echigo, A., Shimane, Y., Usami, R., Itoh, T., Ihara, K., 2011. Gene orders in the upstream of 16S rRNA genes divide genera of the family Halobacteriaceae into two groups. Int. J. Syst. Evol. Microbiol. 62, 188-195. doi:10.1099/ijs.0.031708-0

Narasingarao, P., Podell, S., Ugalde, J. a, Brochier-Armanet, C., Emerson, J.B., Brocks, J.J., Heidelberg, K.B., Banfield, J.F., Allen, E.E., 2012. De novo metagenomic assembly reveals abundant novel major lineage of Archaea in hypersaline microbial communities. ISME J. 6, 81-93. doi:10.1038/ismej.2011.78

Neugebauer, I., Brauer, A., Schwab, M., Waldmann, N., Enzel, Y., Kitagawa, H., Torfstein, A., Frank, U., Dulski, P., Agnon, A., Ariztegui, D., Ben-Avraham, Z., Goldstein, S.L., Stein, M., Party, the D.S., 2014. Lithology of the long sediment record recovered by the ICDP Dead Sea Deep Drilling Project (DSDDP). Quat. Sci. Rev. 102, 149-165.

Nigro, L.M., Hyde, A.S., MacGregor, B.J., Teske, A., 2016. Phylogeography, salinity adaptations and metabolic potential of the candidate division KB1 bacteria based on a partial single cell genome. Front. Microbiol. 7, 1-9. doi:10.3389/fmicb.2016.01266

Oren, A., 1983. Population dynamics of halobacteria in the Dead Sea water column. Limnol. Oceanogr. 28, 1094-1103.

Oren, A., 1993. The Dead Sea—alive again. Cell. Mol. Life Sci. 49, 518-522.

Oren, A., 2008. Microbial life at high salt concentrations: phylogenetic and metabolic diversity. Saline Systems 4, 2. doi:10.1186/1746-1448-4-2

Oren, A., 2010. The dying Dead Sea: The microbiology of an increasingly extreme environment. Lakes Reserv. Res. Manag. 15, 215-222. doi:10.1111/j.1440- 
1770.2010.00435.x

Oren, A., 2015. Halophilic microbial communities and their environments. Curr. Opin. Biotechnol. 33, 119-124. doi:10.1016/j.copbio.2015.02.005

Oren, A., Gunde-Cimerman, N., 2012. Fungal Life in the Dead Sea, in: Raghukumar, C. (Ed.), Progress in Molecular and Subcellular Biology. Springer, Heidelberg, pp. 115132. doi:10.1007/978-3-642-23342-5_6

Oren, A., Gurevich, P., Anati, D., Barkan, E., Luz, B., 1995. A bloom of Dunaliella parva in the Dead Sea in 1992: biological and biogeochemical aspects. Hydrobiologia 297, 173185.

Podell, S., Emerson, J.B., Jones, C.M., Ugalde, J. a, Welch, S., Heidelberg, K.B., Banfield, J.F., Allen, E.E., 2013. Seasonal fluctuations in ionic concentrations drive microbial succession in a hypersaline lake community. ISME J. 8, 979-990.

doi:10.1038/ismej.2013.221

Quast, C., Pruesse, E., Yilmaz, P., Gerken, J., Schweer, T., Yarza, P., Peplies, J., Glöckner, F.O., 2013. The SILVA ribosomal RNA gene database project: improved data processing and web-based tools. Nucleic Acids Res. 41, D590-6. doi:10.1093/nar/gks1219

Rubin, S.S., Marin, I., Gomez, M.J., Morales, E, A., Zekker, I., San Martin, P., Rodriguez, N., Amils, R., 2017. Prokaryotic diversity and community composition in the Salar de Uyuni, a large scale, chaotropic salt flat. Environ. Microbiol. 1-41. doi:10.1111/14622920.

Sankaranarayanan, K., Timofeeff, M.N., Spathis, R., Lowenstein, T.K., Lum, J.K., 2011. Ancient microbes from halite fluid inclusions: optimized surface sterilization and DNA extraction. PLoS One 6, e20683.

Satterfield, C.L., Lowenstein, T.K., Vreeland, R.H., Rosenzweig, W.D., Powers, D.W., 2005. New evidence for $250 \mathrm{Ma}$ age of halotolerant bacterium from a Permian salt crystal. Geology 33, 265-268. doi:10.1130/G21106.1

Sheik, C.S., Reese, B.K., Twing, K.I., Sylvan, J.B., Grim, S.L., Schrenk, M.O., Sogin, M.L., Colwell, F., 2018. Identification and removal of contaminant sequences from ribosomal gene databases: Lessons from the Census of Deep Life. Front. Microbiol. 9, 840. doi:10.3389/FMICB.2018.00840

Sorokin, Di.Y., Messina, E., Smedile, F., Roman, P., Damsté, J.S.S., Ciordia, S., Mena, M.C., Ferrer, M., Golyshin, P.N., Kublanov, I. V., Samarov, N.I., Toshchakov, S. V., La Cono, V., Yakimov, M.M., 2017. Discovery of anaerobic lithoheterotrophic haloarchaea, ubiquitous in hypersaline habitats. ISME J. 11, 1245-1260. doi:10.1038/ismej.2016.203

Tahal Group, Israel., G.S. of, Group, T., Israel, G.S. of, Tahal Group, Israel., G.S. of, 2011. Red Sea - Dead Sea Water Conveyance Study Program : Dead Sea Study.

Thomas, C., Ebert, Y., Kiro, Y., Stein, M., Ariztegui, D., 2016. Microbial sedimentary imprint on the deep Dead Sea sediment. Depos. Rec. 1-21. doi:10.1002/dep2.16

Thomas, C., Grossi, V., Antheaume, I., Ariztegui, D., 2018. Bacterial Recycling of Archaeal Biomass as a New Strategy for Extreme Life in the dead Sea Deep Sediment. EarthArXiv.

Thomas, C., Ionescu, D., Ariztegui, D., 2015. Impact of paleoclimate on the distribution of microbial communities in the subsurface sediment of the Dead Sea. Geobiology 13, 546561. doi:10.1111/gbi.12151 
Thomas, C., Ionescu, D., Ariztegui, D., Party, the D.S., 2014. Archaeal populations in two distinct sedimentary facies of the subsurface of the Dead Sea. Mar. Genomics 17, 53-62. doi:10.1016/j.margen.2014.09.001

Torfstein, A., Gavrieli, I., Katz, A., Kolodny, Y., Stein, M., 2008. Gypsum as a monitor of the paleo-limnological-hydrological conditions in Lake Lisan and the Dead Sea. Geochim. Cosmochim. Acta 72, 2491-2509. doi:10.1016/j.gca.2008.02.015

Torfstein, A., Gavrieli, I., Stein, M., 2005. The sources and evolution of sulfur in the hypersaline Lake Lisan (paleo-Dead Sea). Earth Planet. Sci. Lett. 236, 61-77. doi:10.1016/j.epsl.2005.04.026

van der Wielen, P.W.J.J., Bolhuis, H., Borin, S., Daffonchio, D., Corselli, C., Giuliano, L., D’Auria, G., de Lange, G.J., Huebner, A., Varnavas, S.P., Thomson, J., Tamburini, C., Marty, D., McGenity, T.J., Timmis, K.N., 2005. The enigma of prokaryotic life in deep hypersaline anoxic basins. Science (80-. ). 307, 121-123.

Vreeland, R.H., Jones, J., Monson, A., Rosenzweig, W.D., Lowenstein, T.K., Timofeeff, M., Satterfield, C., Cho, B.C., Park, J.S., Wallace, A., Grant, W.D., 2007. Isolation of live cretaceous (121-112 million years old) halophilic Archaea from primary salt crystals. Geomicrobiol. J. 24, 275-282. doi:10.1080/01490450701456917

Vreeland, R.H., Rosenzweig, W.D., Powers, D.W., 2000. Isolation of a 250 million-year-old halotolerant bacterium from a primary salt crystal. Nature 407, 897-900. doi: $10.1038 / 35038060$

Werner, J., Ferrer, M., Michel, G., Mann, A.J., Huang, S., Juarez, S., Ciordia, S., Albar, J.P., Alcaide, M., La Cono, V., Yakimov, M.M., Antunes, A., Taborda, M., da Costa, M.S., Hai, T., Glöckner, F.O., Golyshina, O. V, Golyshin, P.N., Teeling, H., 2014. Halorhabdus tiamatea: proteogenomics and glycosidase activity measurements identify the first cultivated euryarchaeon from a deep-sea anoxic brine lake as potential polysaccharide degrader. Environ. Microbiol. doi:10.1111/1462-2920.12393

Yakimov, M., Cono, V. La, Slepak, V., La Spada, G., Arcadi, E., Messina, E., Borghini, M., Monticelli, L., Rojo, D., Barbas, C., Golyshina, O., Ferrer, M., Golyshin, P.N., Giuliano, L., 2013. Microbial life in the Lake Medee, the largest deep-sea salt-saturated formation. Sci. Rep. 3. 
Fig. 1: Investigated halite layers from the ICDP Dead Sea Deep Drilling Project cores. Fluid inclusions from the Dead Sea core 5017-A. (A) Small rafts precipitated from the shallow depth of the modern Dead Sea water column (core A-1). (B) Large transparent halite crystals mixed with mud from core A-2. (C) Large transparent halite crystals (core A-21). (D) Alternations of small white halite crystals and large transparent ones from core A-26. (E) Alternations of small white halite crystals and large transparent ones from core A-42. (F) Mix of small white halite crystals and large transparent ones from core A-82. Sample widths are $7 \mathrm{~cm}$.
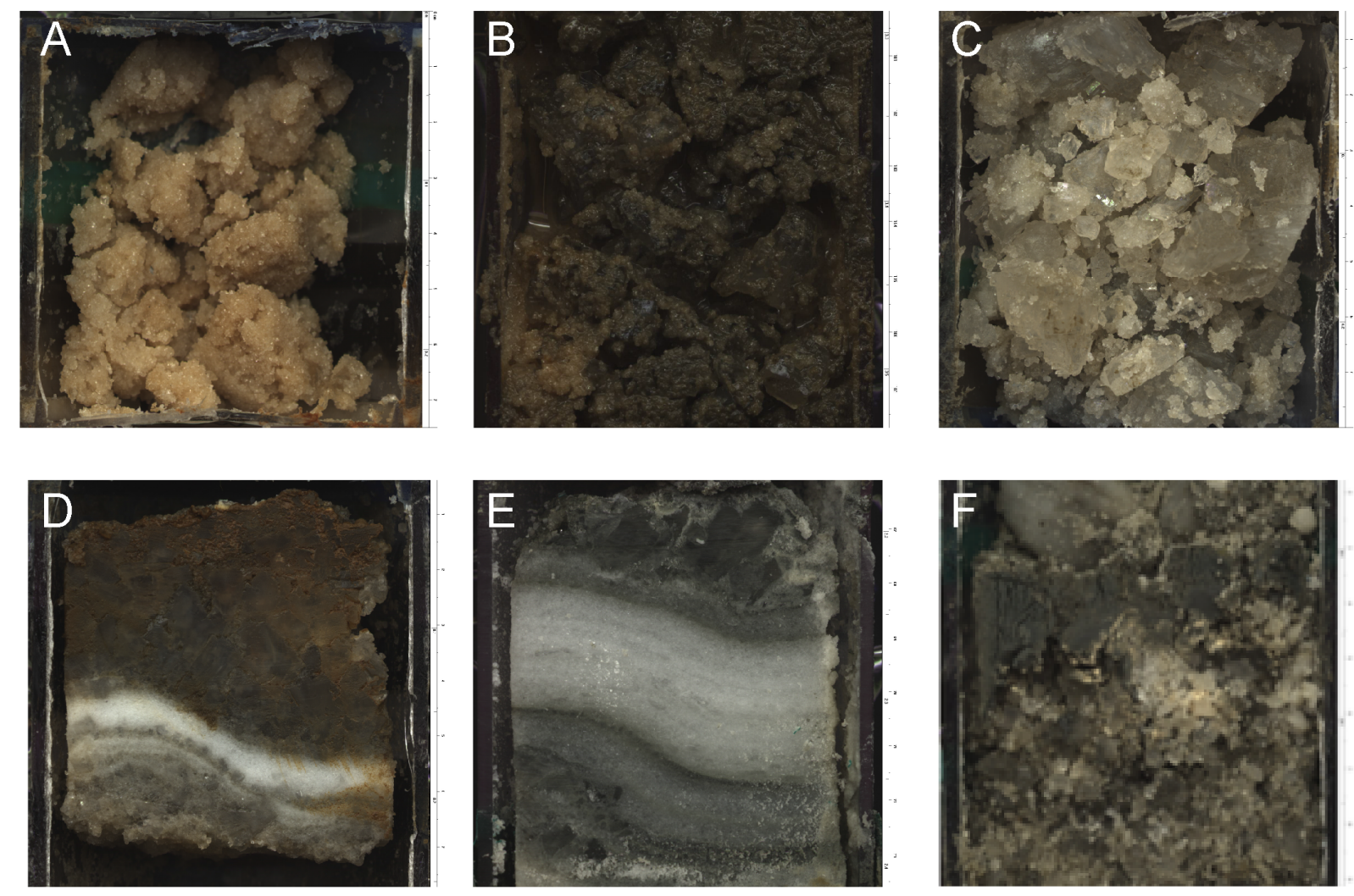
Fig. 2: Fluid inclusions from the Dead Sea core 5017-A. (A) Example of primary cubic fluid inclusions from which DNA extraction was attempted. (B) Halophilic algae Dunaliella enclosed in a fluid inclusion of halite sample in core A-2 (1.3 mblf). Organic matter is not often noticeable under normal light $(\mathrm{C})$ but can be clearly see through its auto-fluorescence under UV light (D). Scale bars are $50 \mu \mathrm{m}$ except for (B).
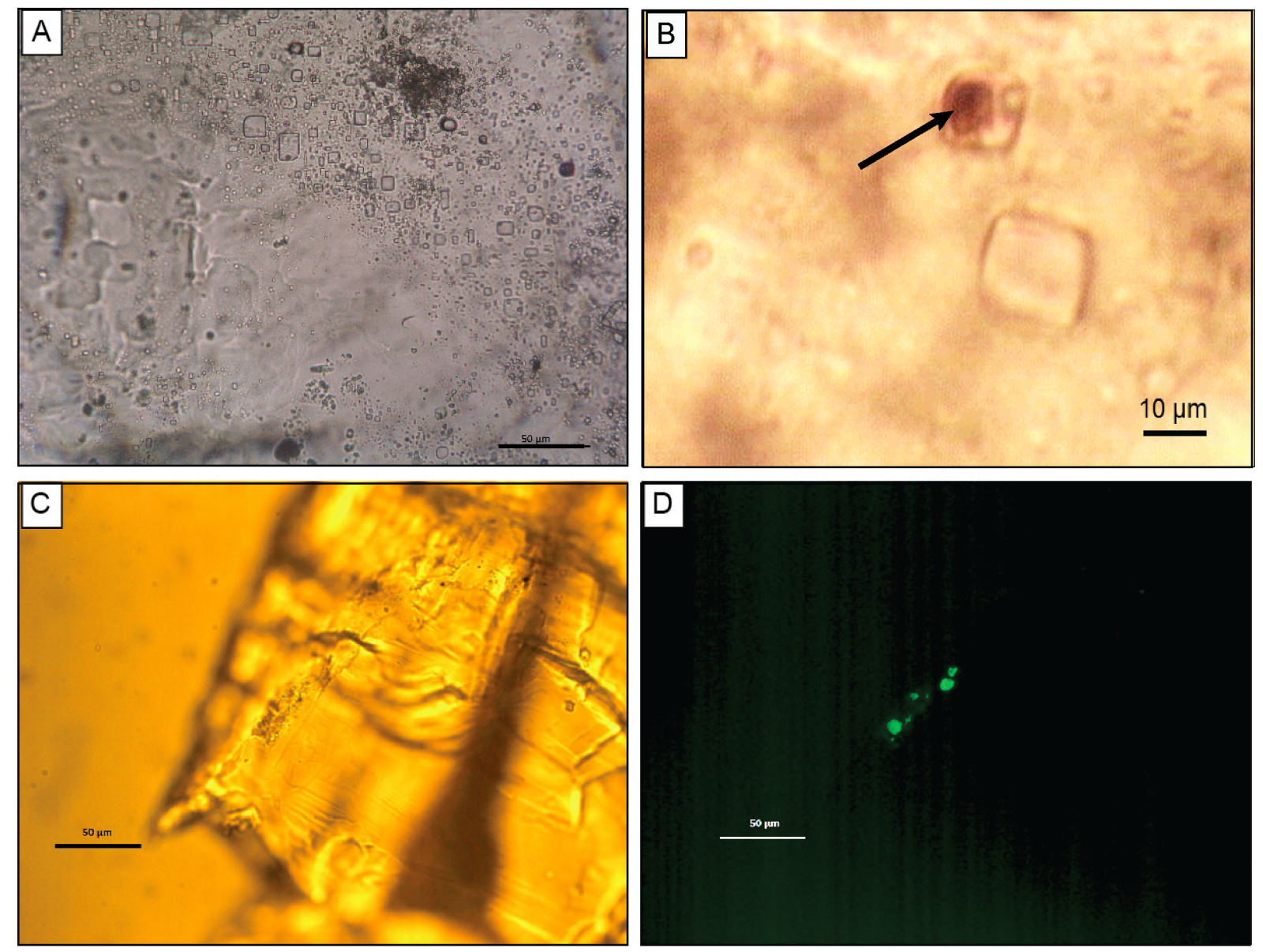
Fig. 3 : Neighbour joining tree of archaeal and bacterial 16S rRNA gene sequences retrieved from halite fluid inclusions from the Dead Sea Deep Drilling Project, together with their associated closest matches (NCBI).

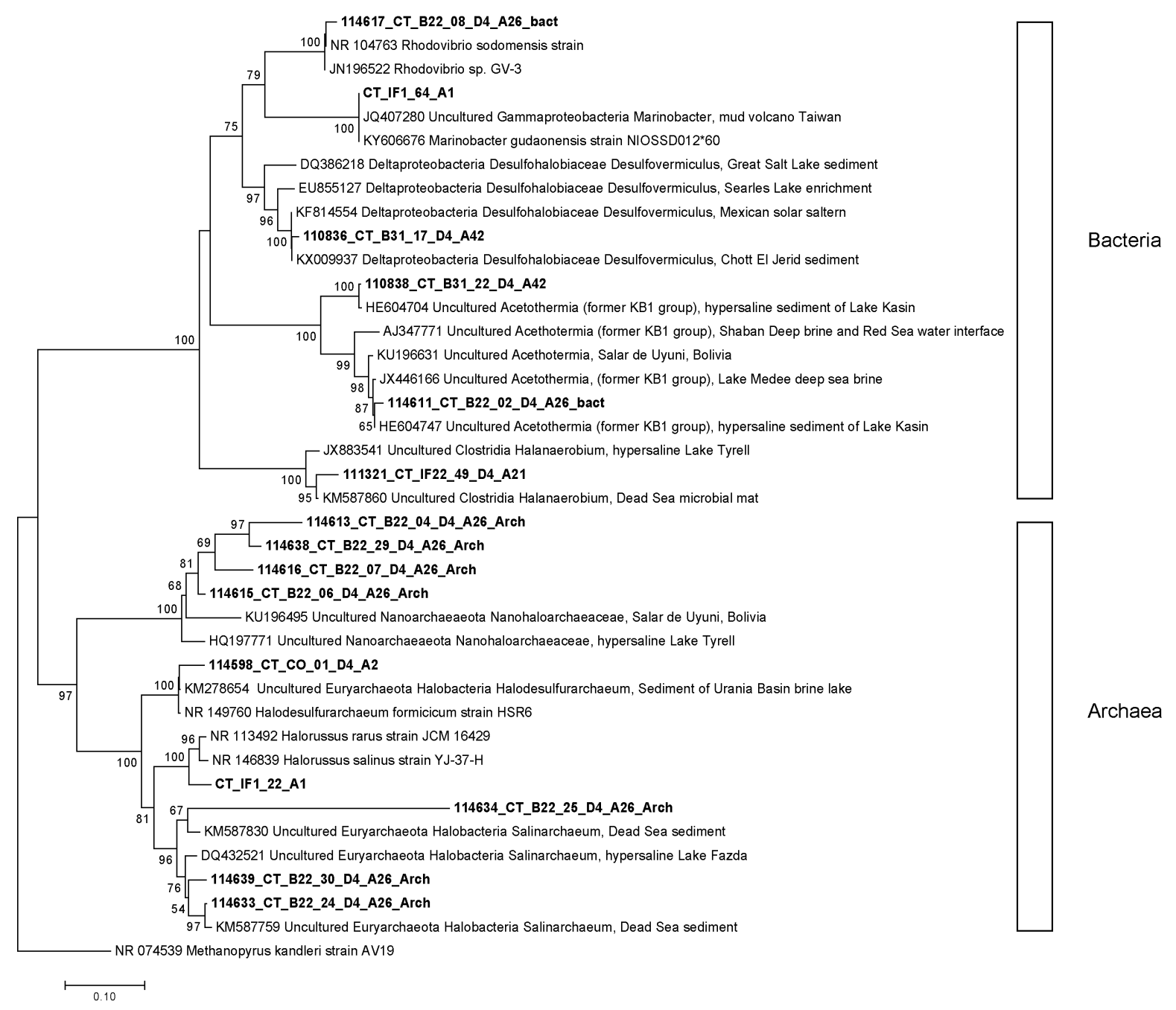


Table 1. Sequences recovered from fluid inclusions of the Dead Sea core samples and information from the closest matches

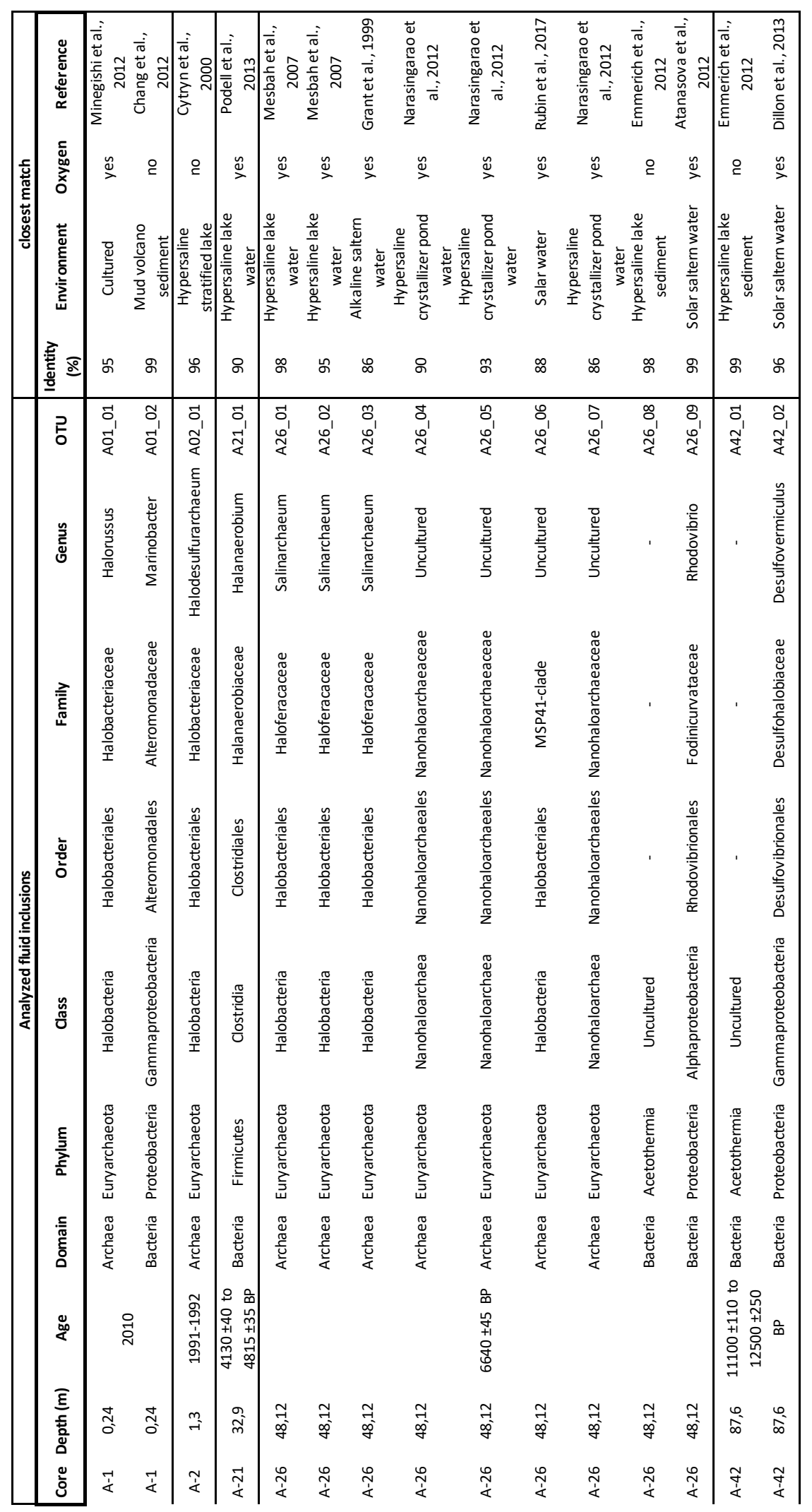

